\title{
The Neber Route to Substituted Indoles
}

\author{
Douglass F. Taber ${ }^{*}$ and Weiwei Tian \\ Department of Chemistry and Biochemistry, University of Delaware, Newark, DE 19716
}

\begin{abstract}<smiles>CC(=O)Cc1ccc(Br)cc1</smiles><smiles>CC1CC1c1ccc(Br)cc1</smiles><smiles>Cc1cc2ccc(Br)cc2[nH]1</smiles>

Two complementary procedures have been developed for the conversion of the oximes of $\alpha$-aryl ketones to azirines. On heating, the azirines rearrange smoothly to the corresponding indoles. The overall transformation offers a versatile route to indoles, complementary to the Fischer indole synthesis.
\end{abstract}

\begin{abstract}
Indoles are ubiquitous components both of physiologically-active natural products and of important pharmaceuticals. ${ }^{1}$ Progress in the development of indole chemistry depends on the development of efficient synthetic routes to a variety of substitution patterns. We report what appears to be a general indole synthesis starting from alkyl-substituted benzene derivatives. This approach is complementary to the Fischer indole synthesis, ${ }^{2}$ that starts with an aminated benzene ring, and to other existing methods for indole construction from disubstituted aromatics. ${ }^{3}$ The reduction to practice of this route ${ }^{4}$ to indoles opens a new expanse of pharmaceutical space for exploration.
\end{abstract}

We took as our lead the observation that the only existing approach to the preparation of indoles that started from an alkyl-substituted benzene, the pyrolysis of $\alpha$-azido cinnamates (Scheme 1), was known ${ }^{4 b}$ to proceed by way of the intermediate azirine 2 . We reasoned that $\alpha$-aryl azirines such as $\mathbf{5 a}$, available by Neber reaction ${ }^{5,6}$ of the oximes derived from $\alpha$-aryl ketones such as $\mathbf{4 a}$, could also undergo thermolytic rearrangement to give the indole. ${ }^{4,8}$

The challenge proved to be the efficient conversion of the oxime derived from the $\alpha$-aryl ketone to the azirine. ${ }^{7}$ Activation of the oxime $\mathrm{OH}$ with a leaving group is an invitation to competing Beckmann rearrangement and/or Beckmann fragmentation. We eventually developed two complementary procedures (Table 1) for effecting this transformation. For monoaryl acyclic ketones such as $4 \mathbf{a}$, exposure of the oxime to $\mathrm{MsCl}$ and $\mathrm{Et}_{3} \mathrm{~N}$ at $20{ }^{\circ} \mathrm{C}$ followed by the addition of DBU led smoothly to the azirine. For the diaryl ketone $\mathbf{4 c}$ and the cyclic ketone 4e, an alternative procedure, Mitsunobu cyclization of the oxime with DIAD/ $\mathrm{Bu}_{3} \mathrm{P}$ or $\mathrm{Ph}_{3} \mathrm{P}$, was more satisfactory. We were pleased to observe that each of the azirines in Table 1 was stable to chromatographic purification and to storage. The thermal rearrangement to the indole (sealed tube, $o$-xylene) worked smoothly for each of the azirines. The temperature for the rearrangement ranged from $170{ }^{\circ} \mathrm{C}$ (entry 1 ) down to less

*taberdf@udel.edu . SUPPORTING INFORMATION. Experimental details and spectra for all new compounds. This material is available free of charge via the internet at http://pubs.acs.org. 
than $40{ }^{\circ} \mathrm{C}$ (entry 5). In the latter case, the azirine could not be isolated, because it rearranged to the indole as it was formed.

We were curious as to the mechanism of the azirine to indole rearrangement. Following the literature, ${ }^{4 a}$ we expected (Scheme 2) that the rate-determining step would be cleavage of the $\mathrm{C}-\mathrm{N}$ single bond. There were, then, two limiting mechanisms: formation of the nitrene $\mathbf{8}$ followed by insertion into the Ar- $\mathrm{H} \sigma$ bond to give $\mathbf{9}$, or $\pi$ participation from the aromatic ring to give 10, which would reorganize to $\mathbf{1 1}$ and then $\mathbf{9}$.

To probe this question, we carried out two additional cyclizations, of $\mathbf{1 2}$, and of the intermediate unstable azirine derived from $\mathbf{1 5}$ (Scheme 3). We reasoned that the $\sigma$ insertion (intermediate 8) would lead to a substantial isotope effect. In fact, there was only a very minor isotope effect $\left(\leq 10 \%,{ }^{1} \mathrm{H}\right.$ NMR integration) in the formation of $\mathbf{1 3}$ and $\mathbf{1 4} .{ }^{10}$

There was still the formal possibility that the nitrene $\mathbf{8}$ (Scheme 2) was cyclizing much more quickly than it could rotate. To assess this, we rearranged the azirine derived from $\mathbf{1 5}$. In fact, there was a significant preference for insertion into the more electron-rich aromatic ring, to give 17, suggesting that the cyclization is proceeding by way of the $\pi$ mechanism. The observed preference for $\mathbf{1 7}$ may be of some preparative utility.

The cyclodehydration of the oximes of $\alpha$-aryl ketones to indoles, sought for at least fifty years, ${ }^{8}$ has now been reduced to practice. We expect that this approach will be particularly useful for the preparation of indoles having highly-substituted benzene rings.

\section{Supplementary Material}

Refer to Web version on PubMed Central for supplementary material.

\section{Acknowledgments}

We thank Koichi Narasaka and Gordon W. Gribble for helpful discussions. This work was supported by the National Institutes of Health (GM 60287).

\section{REFERENCES}

(1). For leading references to the physiological activity of indole derivatives, see (a) Kam T-S, Choo Y-M. Helv. Chim. Acta. 2004; 87:991. (b) Kuethe JT, Wong A, Qu C, Smitrovich J, Davies IW, Hughes DL. J. Org. Chem. 2005; 70:2555. [PubMed: 15787543] (c) Van Zandt MC, Jones ML, Gunn DE, Geraci LS, Jones JH, Sawicki DR, Sredy J, Jacot JL, DiCioccio AT, Petrova T, Mitschler A, Podjarny AD. J. Med. Chem. 2005; 48:3141. [PubMed: 15857120]

(2). For leading references to current applications of the Fischer indole synthesis, see Wagaw S, Yang BY, Buchwald SL. J. Am. Chem. Soc. 1999; 121:10251.

(3). For a review of methods for indole synthesis, see (a) Gribble GW. J. C. S. Perkin 1. 2000:1045. For more recent references, see (b) Rutherford JL, Rainka MP, Buchwald SL. J. Am. Chem. Soc. 2002; 124:15168. [PubMed: 12487580] (c) Kamijo S, Yamamoto Y. Angew. Chem. Int. Ed. 2002; 41:3230. (d) Arisawa M, Terada Y, Nakagawa M, Nishida A. Angew. Chem. Int. Ed. 2002; 41:4732. (e) Smith AB, Kanoh N, Ishiyama H, Minakawa N, Rainier JD, Hartz RA, Cho YS, Cui H, Moser WH. J. Am. Chem. Soc. 2003; 125:8228. [PubMed: 12837093] (f) Siebeneicher H, Bytschkov I, Doye S. Angew. Chem. Int. Ed. 2003; 42:3042. (g) Shimada T, Nakamura I, Yamamoto Y. J. Am. Chem. Soc. 2004; 126:10546. [PubMed: 15327305] (h) Willis MC, Brace GN, Holmes IP. Angew. Chem. Int. Ed. 2005; 44:403. (i) Baran PS, Guerrero CA, Ambhaikar NB, Hafensteiner BD. Angew. Chem. Int. Ed. 2005; 44:606. (j) Herzon SB, Myers AG. J. Am. Chem. Soc. 2005; 127:5342. [PubMed: 15826171] (k) Dunetz JR, Danheiser RL. J. Am. Chem. Soc. 2005; 127:5776. [PubMed: 15839661] 
(4). There have been scattered reports of the rearrangement of aryl azirines to indoles: (a) Padwa A, Smolanoff J, Tremper A. J. Org. Chem. 1976; 41:543. (b) Isomura K, Ayabe G, Hatano S, Taniguchi H. J. C. S., Chem. Commun. 1980:1252. (c) Russell GA, Yao C-F, Tashtoush HI, Russell JE, Dedolph DF. J. Org. Chem. 1991; 56:663. (d) Inui H, Murata S. J. Am. Chem. Soc. 2005; 127:2628. [PubMed: 15725019] (e) For Rh catalysis, see Alper H, Prickett JE. J. C. S., Chem. Commun. 1976:483. (f) For Pd catalysis, see Isomura K, Uto K, Taniguchi H. J. C. S., Chem. Commun. 1977:664.

(5). For the development of the Neber synthesis of azirines, see (a) Neber PW, Burgard A. Justus Liebigs Ann. Chem. 1932; 493:281. (b) Neber PW, Huh G. Justus Liebigs Ann. Chem. 1935; 515:283.

(6). For recent uses of the Neber reaction, see (a) Chung JYL, Ho G-J, Chartrain M, Roberge C, Zhao D, Leazer J, Farr R, Robbins M, Emerson K, Mathre DJ, McNamara JM, Hughes DL, Grabowski EJJ, Reider PJ. Tetrahedron Lett. 1999; 40:6739. (b) Sakai T, Liu Y, Ohta H, Korenaga T, Ema T. J. Org. Chem. 2005; 70:1369. [PubMed: 15704972] (c) Garg NK, Caspi DD, Stoltz BM. J. Am. Chem. Soc. 2005; 127:5970. [PubMed: 15839697]

(7). For alternative procedures for the preparation of azirines from $\alpha$-aryl ketones, see Barcus RL, Hadel LM, Johnston LJ, Platz MS, Savino TG, Scaiano JC. J. Am. Chem. Soc. 1986; 108:3928. In our hands, these procedures were not as efficient as those that we report here.

(8). The cyclodehydration of the oxime of an $\alpha$-aryl ketone to give the indole is a goal that dates back at least fifty years: Loffler A, Ginsburg D. Nature. 1953; 172:820. Our experience with the oximes of $\alpha$-aryl ketones that we have studied is that they sometimes sublime on heating under reduced pressure, but they do not give even traces of indole.

(9). Several of the substances reported here were previously described: (a) 5c: Padwa A, Rosenthal RJ, Dent W, Filho P, Turro NJ, Hrovat DA, Gould IR. J. Org. Chem. 1984; 49:3174. (b) 6c: Fuerstner A, Jumbam DN. Tetrahedron. 1992; 48:5991. (c) 15: Katritzky AR, Toader D, Xie L. J. Org. Chem. 1996; 61:7571. [PubMed: 11667690] (d) 16: Baccolini G, Dalpozzo R, Todesco PE. J. Chem. Soc. Perkin Trans. 1. 1988:971. (e) 17: Ikuta S, Shiro M, Ogawa K. 2005US 6,861,444 B2

(10). For leading references to primary and secondary kinetic isotope effects, see Lykakis IN, Orfanopoulos M. Tetrahedron Lett. 2005; 46:7835. 


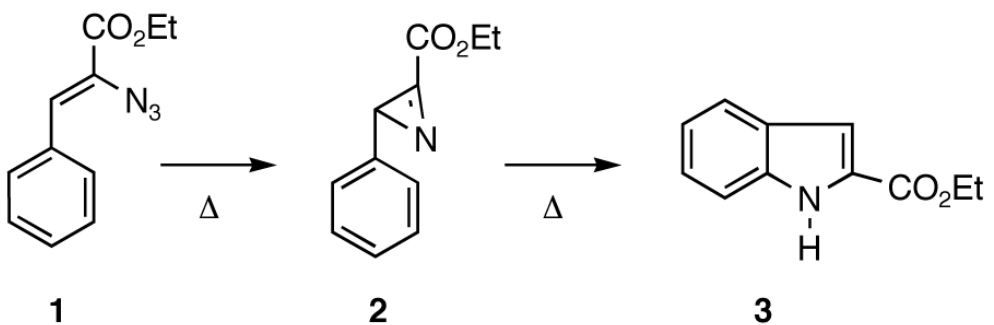<smiles>CC(=O)Cc1ccc(Br)cc1</smiles>

Scheme 1. 


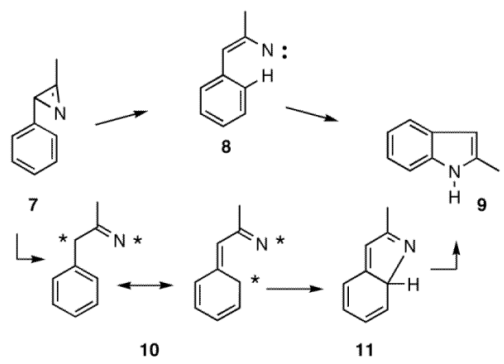

Scheme 2. 

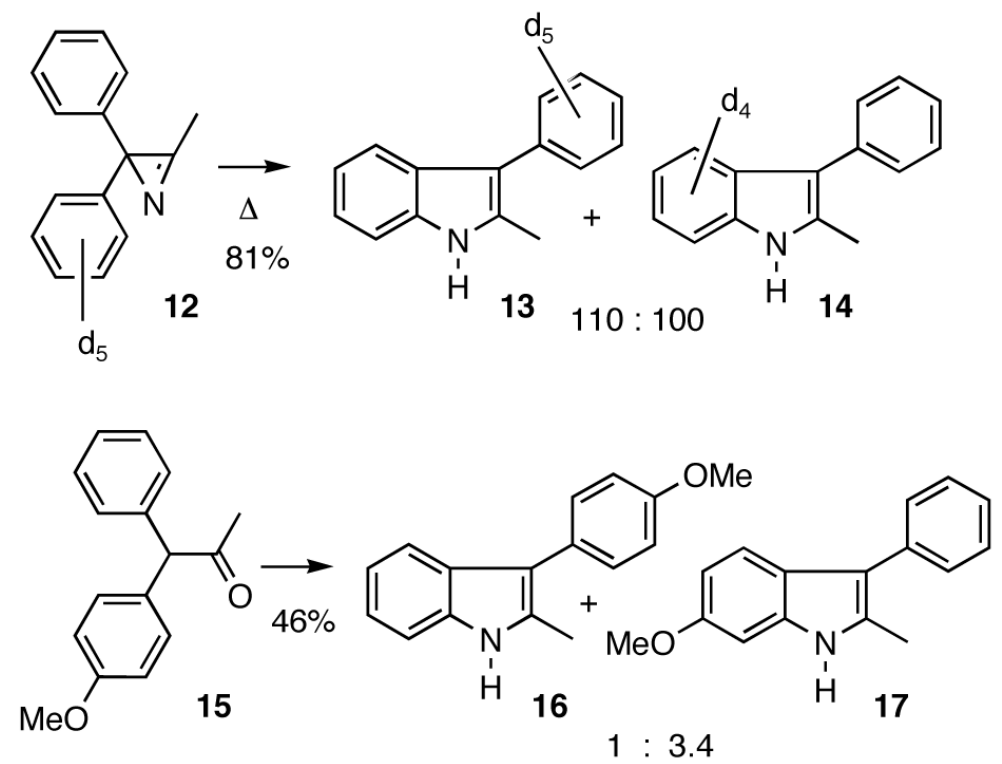

Scheme 3. 


\section{Table 1}

Indoles from $\alpha$-Aryl Ketones

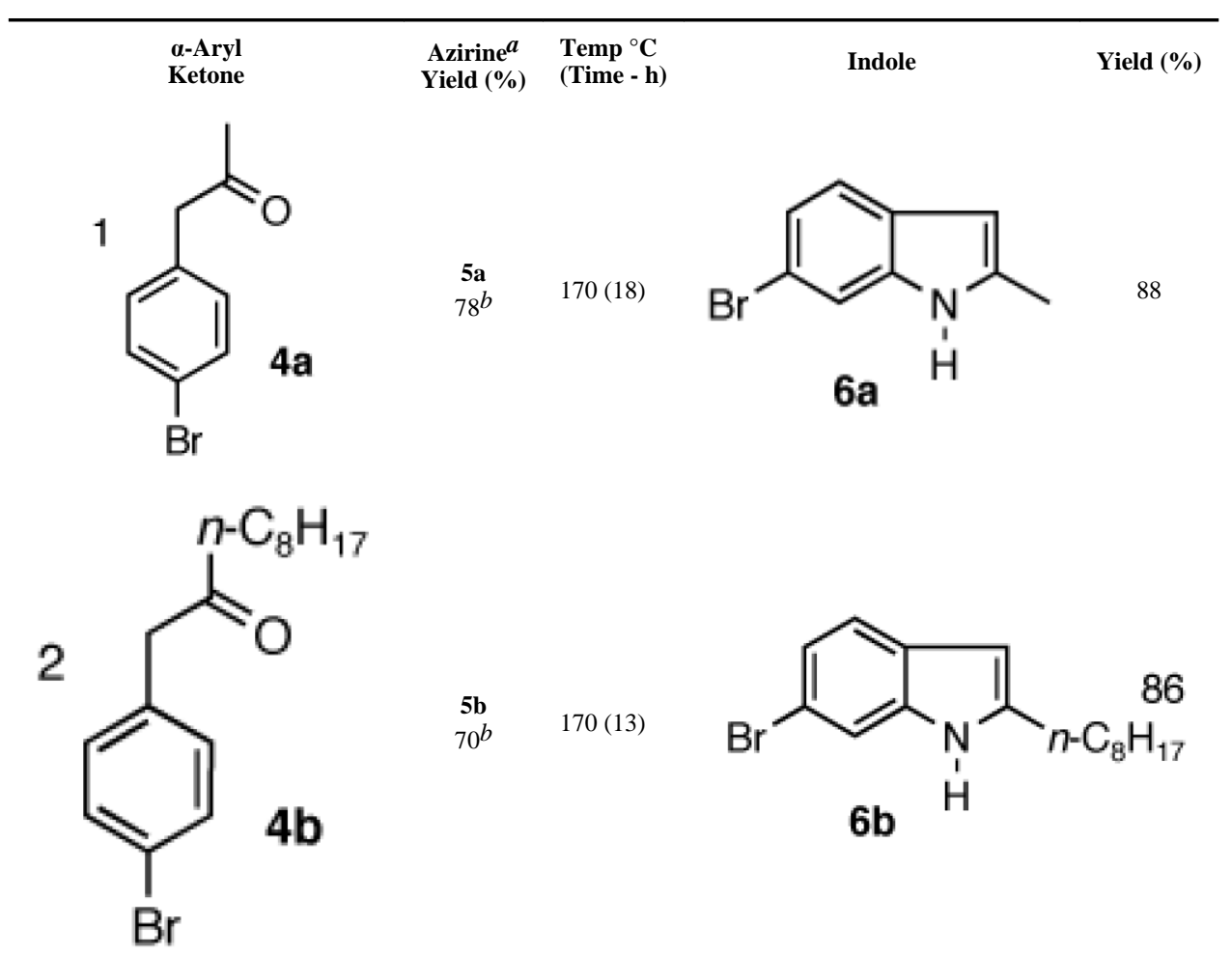<smiles>CC(=O)C(c1ccccc1)c1ccccc1</smiles>

$\mathbf{5 c}^{c}$
$91^{d}$

$150(16)$<smiles>Cc1c(-c2ccccc2)c2ccccc2n1C</smiles><smiles>CC(=O)Cc1ccccc1Br</smiles><smiles>Cc1cc2c(Br)cccc2[nH]1</smiles> 


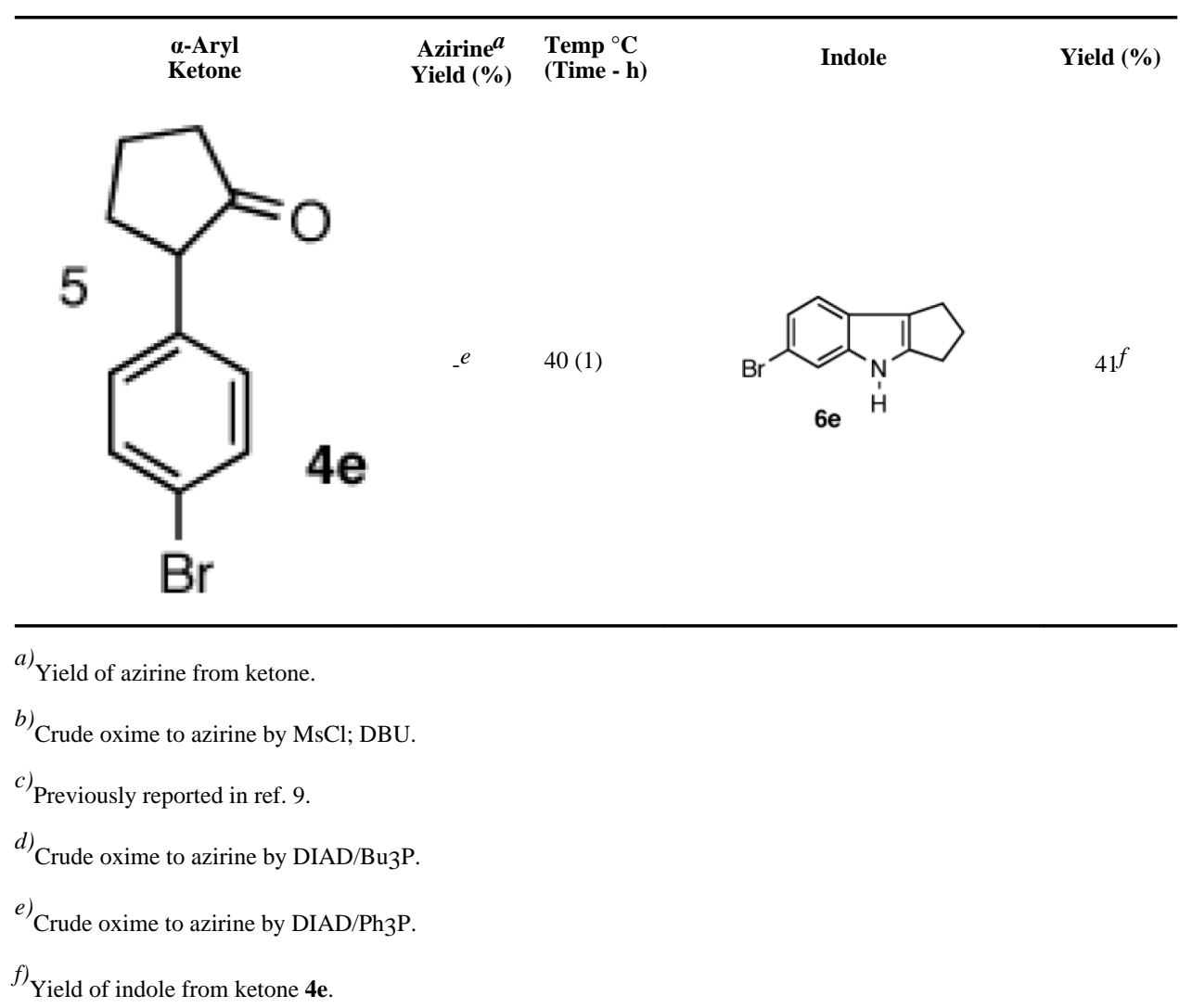

